\title{
A Rare Tumor of the Lung: Sarcomatoid Carcinoma
}

\author{
Coşkun Doğan, ' Sevda Şener Cömert,' Benan Çağlayan, 'Banu Salepçi, \\ Seda Beyhan Sağmen, ${ }^{1}$ Ali Fidan, ${ }^{1}$ Şermin Kökten Çoban ${ }^{2}$
}

\author{
'Department of Pulmonary \\ Diseases, University of Health \\ Sciences, Kartal Dr. Lütfi Kırdar \\ Training and Research Hospital, \\ İstanbul, Turkey \\ ${ }^{2}$ Department of Pathology, \\ University of Health Sciences, \\ Kartal Dr. Lütfi Kırdar Training and \\ Research Hospital, İstanbul, Turkey
}

Submitted: 26.10.2016 Accepted: 23.05.2017

Correspondence: Coşkun Doğan, Kafkas Üniversitesi Tıp Fakültesi, Göğüs Hastalıkları Anabilim Dalı, Kars, Turkey

E-mail: coskund24@yahoo.com

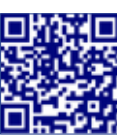

Keywords: Lung cancer; sarcomatoid carcinoma; ultrasonography.

\begin{abstract}
Sarcomatoid carcinoma of the lung is a rare, poorly differentiated, low-grade carcinoma in the non-small cell lung cancer (NSCLC) group. It is a very aggressive tumor; the 5-year survival rate in patients with sarcomatoid carcinoma does not exceed $20 \%$. There are a limited number of retrospective screenings of sarcomatoid carcinoma cases and case reports in the literature. The diagnosis, treatment, and prognostic features of sarcomatoid carcinoma are not well known compared with other NSCLCs. However, studies of sarcomatoid carcinoma have demonstrated that the prognosis is poor and response to standard chemotherapy treatment is not as good as seen with other NSCLCs. Presently described is a rare case diagnosed by thoracic ultrasonography-guided transthoracic biopsy.
\end{abstract}

\section{INTRODUCTION}

Sarcomatoid carcinoma of the lung is a rare, poorly differentiated carcinoma in the non-small cell lung cancer (NSCLC) category. The prevalence among all lung tumors is very low, representing $0.3 \%$ to $1.3 \%$. It is frequently seen in the upper lobes, peripherally located, with an average size of $5 \mathrm{~cm}$, and seen as a mass with a necrotic, or occasionally, a cavitary center. It is diagnosed mostly in smokers and patients of average age of 65 years. ${ }^{[l]}$ The 5 -year survival rate in sarcomatoid carcinoma, which has quite an aggressive course, does not exceed $20 \%$. Sarcomatoid carcinoma is categorized as a separate group in the World Health Organization's histological classification published in 2015. There are 2 cell types: sarcomatoid or sarcomalike, with giant and/or spindle cells. The sarcomatoid carcinoma group consists of pleomorphic carcinoma, spindleshaped carcinoma, giant-cell carcinoma, carcinosarcoma, and pulmonary blastoma. ${ }^{[2]}$
Transthoracic biopsy (TTB) carried out with the guidance of thoracic ultrasound (US) is easier to access compared with other, similar diagnostic procedures, and is cheaper, has greater diagnostic efficiency, and a lower complication rate. There is no radiation exposure, it is less invasive, minimally traumatic, can be performed without general anesthesia or sedation, is suitable for real-time operation, and can be manipulated/repeated in order to avoid cavities or necrotic areas. ${ }^{[3,4]}$

Presently described is a very rare sarcomatoid lung tumor with peripheral localization in the lung that was diagnosed with TTB under guidance of thoracic US.

\section{CASE REPORT}

A 75-year-old male patient was referred to the chest diseases polyclinic with back pain complaint ongoing for about 3 months. A well-defined mass lesion was detected 


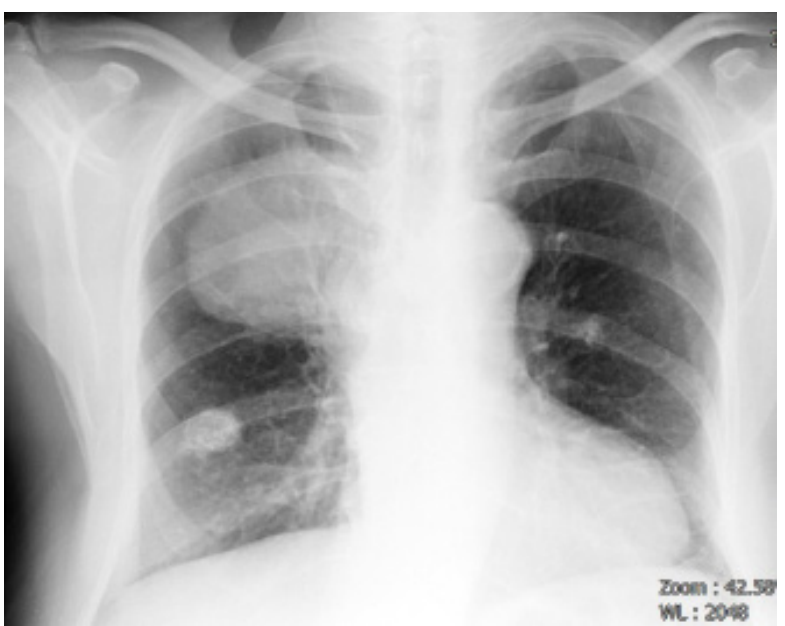

Figure 1. A well-defined mass lesion in the upper right middle zone with an approximate size of $10 \times 10 \mathrm{~cm}$, as well as a calcified nodule in the right lower zone between the fourth and fifth costae in the posterioranterior chest X-ray.

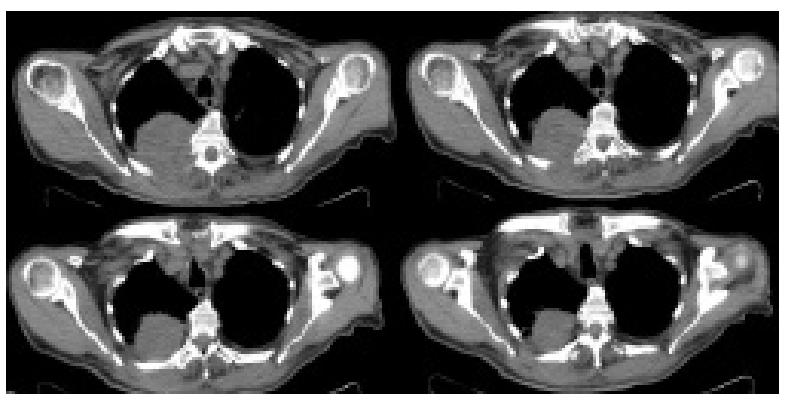

Figure 2. Irregularly contoured mass lesion approximately of $99 \times 87 \times 80 \mathrm{~mm}$ in size, causing destruction of the posterior of fifth and sixth costae was observed in the right upper lobe, extending to the extrathoracic muscle groups.

in the upper right middle zone on posterioranterior chest $X$-ray with an approximate size of $10 \times 10 \mathrm{~cm}$ (Figure I). The thoracic computed tomography (CT) revealed an irregularly contoured mass lesion with an approximate size of $99 \times 87 \times 80 \mathrm{~mm}$, causing destruction of the posterior aspect of the fifth and sixth costae in the right upper lobe and extending to the extrathoracic muscle groups (Figure 2). Physical examination of the lungs and other systemic examinations did not reveal any pathological finding. Hemogram, biochemical parameters, and coagulometry results were normal. The patient's history indicated lymphoma treatment 5 years earlier at another medical center, as well as treatment for squamous cell cancer of the nose I year earlier. Fine-needle aspiration and Tru-Cut biopsy (Becton Dickinson and Co., Franklin Lakes, NJ, USA) under guidance of thoracic US was performed. The pathology was reported as CK7 positive, TTFI and HMB45 negative tumor with morphological characteristics suggesting sarcomatoid carcinoma (Figure 3). Positron emission tomography (PET)/CT results indicated primary lesion with maximum standardized uptake value (SUV-max) of 22.9

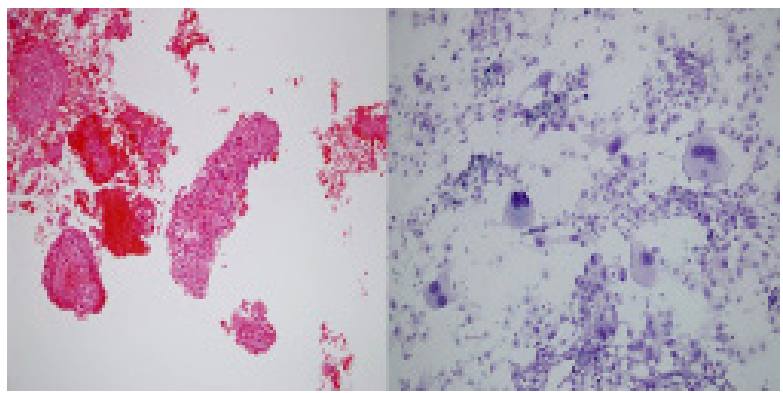

Figure 3. Occasional spindle-shaped giant tumor cells with bizarre nuclei and necrotic debris. (Giemsa x200; H\&E x100).

and lymphadenopathies with necrotic component in the right upper and lower paratracheal areas of the mediastinum (SUV-max: 1I.7), hypermetabolic metastatic lesions measuring $23 \times 24 \mathrm{~cm}$ in the right third costa (SUV-max: 8.2), and right cervical lymphadenopathy (SUV-max: 9.8), $3 \times 3 \mathrm{~cm}$ in size (Figure 4). Due to third costa involvement, cervical lymph node metastasis, and multiple mediastinal lymph node metastases, the evaluation was advanced stage cancer. The patient was referred to the oncology polyclinic. Chemotherapy (paclitaxel/carboplatin) and radiotherapy treatment were initiated concurrently. The patient died in the seventh month of treatment.

\section{DISCUSSION}

Sarcomatoid carcinoma is rarely seen, and usually involves the upper lobes of the lungs and peripheral regions. It has a very aggressive course compared with other tumors of the lungs. This case of sarcomatoid lung carcinoma was presented because it is so rare, and because it was diagnosed using TTB guided by thoracic US.

The diagnosis, treatment, and prognostic features of sarcomatoid carcinoma are less known than other, more common, lung tumors. There are few reports in the literature, and they are mostly case reports and retrospective screenings of a limited number of cases. Huang et al..$^{[5]}$

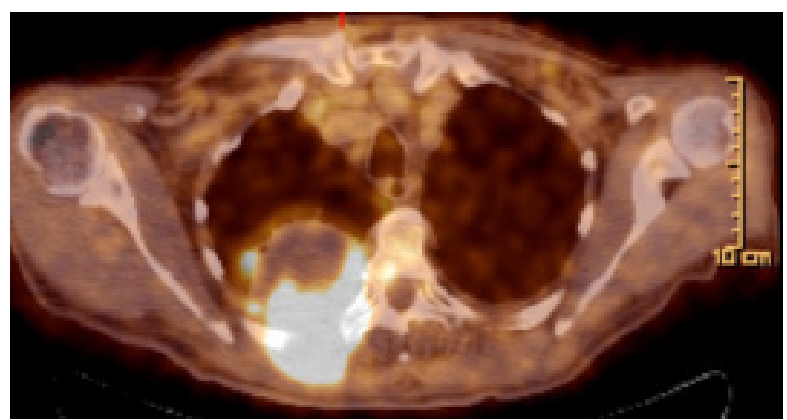

Figure 4. Positron emission tomography/computed tomography image demonstrating a mass lesion measuring $99 \times 87 \times 80$ $\mathrm{mm}$ with maximum standardized uptake value of 22.9 on the posterior aspect of the right upper lobe. 
reported in a study in which they researched the features of sarcomatoid carcinomas in $5 \mathrm{I}$ patients from between January 2005 and December 2012 that they found a survival rate for I, 2, 3, and 5 years of $45.5 \%, 35.8 \%, 28.2 \%$ and $20.1 \%$, respectively, and mean life span of patients was I3.3 months, while median survival time of patients was 6 months. They demonstrated in their study that tumor size and distant metastasis were independent prognostic factors, and they drew attention to the fact that surgical resection and postoperative adjuvant chemotherapy in sarcomatoid carcinoma may lead to better prognosis. Surgical treatment was not performed in the present case because the patient had distant organ metastases. Our patient died 7 months after being diagnosed. The survival time is consistent with the literature.

Studies have shown that sarcomatoid carcinoma has a statistically significantly high $(p<0.000 \mathrm{I})$ glucose uptake seen in PET/CT compared with other histological types. ${ }^{[6-8]}$ In the present case, the primary lesion had a high SUV-max of 22.9.

Sputum cytology is not useful in the diagnosis of sarcomatoid carcinoma. Bronchoscopy biopsy or percutaneous TTB is more valuable in diagnosis. ${ }^{[9]}$ TTB procedure guided by US has been utilized effectively and safely for a long time in peripherally located lesions of the lungs. Important advantages include the lack of exposure to radiation for both the patient and the physician, compared with biopsies accompanied by CT and fluoroscopy, and that the procedure can be conducted in real time (the needle can be tracked within the target lesion). The diagnostic success of TTB under US guidance has been reported to be between $64.5 \%$ and $96.8 \%$, and complication rate is low. $[4,10]$ Our case was diagnosed by TTB under thorax US guidance. Studies conducted have shown that sarcomatoid carcinoma does not respond well to standard chemotherapy (carboplatin/paclitaxel) treatment. Surgical treatment outperforms chemotherapy in early stage tumors. Although currently there are insufficient data with regard to targeted chemotherapies, such as crizotinib and sunitinib, cancer immunotherapy, or vaccines, there are some promising experimental studies. ${ }^{[1]}$

One of the most extensive studies of sarcomatoid carcinoma was reported by Gu et al. ${ }^{[12]}$ They examined a total of 95 pulmonary sarcomatoid carcinomas between 2008 and 2014. These researchers had important results that were similar to previous studies in terms of what was learned about patient age; gender; smoking history; diagnostic methods; tumor localization; tumor size; tumor, node, and metastasis stages; treatment options; and survival rates in sarcomatoid carcinoma cases. It was determined that $57.9 \%$ of the patients were older than 60 years of age, $84.2 \%$ were male, $41.1 \%$ were smokers, $77.9 \%$ of the tumors were peripheral, $41.1 \%$ were in the right upper lobe while $29.5 \%$ were in the left upper lobe, $40 \%$ was larger than $5 \mathrm{~cm}$ in size, and at the time of diagnosis, $24.2 \%$ were at stage I, $27.4 \%$ were at stage II, $31.6 \%$ were at stage III, and $16.8 \%$ were at stage IV. Median survival rate was 1 I.54 months for all patients, and the 5-year survival rate was $21 \%$. It was concluded as a result of the study that lung sarcomatoid carcinoma is rare, and has a poor response to standard chemotherapy treatments and a poor prognosis.

In conclusion, our case of rarely seen lung tumor with poor prognosis was consistent with the literature.

Informed Consent

Consent was obtained from the patient who participated in this study.

Peer-review

Internally peer-reviewed.

Authorship Contributions

Surgical and Medical Practices: C.D.; Concept: C.D.; Design: C.D.; Data collection \&/or processing: S.B.S.; Analysis and/or interpretation: B.S.; Literature search: D.E.I.; Writing: C.D.; Critical review: A.F., S.Ş.C.

Conflict of Interest

None declared.

\section{REFERENCES}

1. Chen CH, Chen WM, Tung SY, Wu CS, Tong WL, Lee KF, et al. Gastrointestinal metastasis from primary sarcomatoid carcinoma of the lung: a case report and review of the literature. World J Surg Oncol 2015;13:174.

2. Yılmazbayhan D, Özlük Y. Küçük hücreli akciğer karsinomlarında patoloji. Journal of Clinical and Analytical Medicine 2010;1:8-15.

3. Ikezoe J, Sone S, Higashihara T, Morimoto S, Arisawa J, Kuriyama $\mathrm{K}$. Sonographically guided needle biopsy for diagnosis of thoracic lesions. AJR Am J Roentgenol 1984;143:229-34.

4. Wang HC, Yu CJ, Chang DB, Yuan A, Lee YC, Yang PC, et al. Transthoracic needle biopsy of thoracic tumours by a colour Doppler ultrasound puncture guiding device. Thorax 1995;50:1258-63.

5. Huang SY, Shen SJ, Li XY. Pulmonary sarcomatoid carcinoma: a clinicopathologic study and prognostic analysis of 51 cases. World J Surg Oncol 2013;11:252.

6. Pelosi G, Melotti F, Cavazza A, Rossi G, Maisonneuve P, Graziano P, et al. A modified vimentin histological score helps recognize pulmonary sarcomatoid carcinoma in small biopsy samples. Anticancer Res 2012;32:1463-73.

7. Kaira K, Horie Y, Ayabe E, Murakami H, Takahashi T, Tsuya A, et al. Pulmonary pleomorphic carcinoma: a clinicopathological study including EGFR mutation analysis. J Thorac Oncol 2010;5:460-5.

8. Leone A, Graziano P, Gasbarra R, Paone G, Cardillo G, Mancuso A, et al. Identification of EGFR mutations in lung sarcomatoid carcinoma. Int J Cancer 2011;128:732-5.

9. Franks TJ, Galvin JR. Sarcomatoid carcinoma of the lung: histologic criteria and common lesions in the differential diagnosis. Arch Pathol Lab Med 2010;134:49-54. 
10. Wang HC, Yu CJ, Chang DB, Yuan A, Lee YC, Yang PC, et al. Transthoracic needle biopsy of thoracic tumours by a colour Doppler ultrasound puncture guiding device. Thorax 1995;50:1258-63.

11. Laursen CB, Naur TM, Bodtger U, Colella S, Naqibullah M, Minddal V, et al. Ultrasound-guided Lung Biopsy in the Hands of Respiratory Physicians: Diagnostic Yield and Complications in 215 Consecutive Patients in 3 Centers. J Bronchology Interv Pulmonol
2016;23:220-8.

12. Jiang X, Liu Y, Chen C, Zhan Z, Yan Q, Guo Y, et al. The value of biomarkers in patients with sarcomatoid carcinoma of the lung: molecular analysis of 33 cases. Clin Lung Cancer 2012;13:288-96.

13. Gu L, Xu Y, Chen Z, Pan Y, Lu S. Clinical analysis of 95 cases of pulmonary sarcomatoid carcinoma. Biomed Pharmacother 2015;76:134-40.

\section{Akciğerin Nadir Görülen Bir Tümörü: Sarkomatoid Karsinom}

Akciğerin sarkomatoid karsinomları küçük hücreli dışı akciğer kanserleri (KHDAK) sınıfında nadir görülen, az diferansiye karsinomlardır. OIdukça agresif seyirli olan sarkomatoid karsinomlarda beş yıllık sağ kalım oranı \%20'yi geçmemektedir. Literatürde çoğunlukla olgu bildirimleri ve sınırı sayıda olguların geriye dönük taranması şeklinde çalışmalar olan sarkomatoid karsinomların bu yüzden tanı, tedavi ve prognostik özellikleri akciğerin diğer KHDAK'lerine kıyasla az bilinir. Yapılan çalışmar sarkomatid karsinomların akciğerin diğer KHDAK'lerine kıyasla kötü prognozlu ve standart kemoterapi tedavilerine yanıtının kötü olduğunu göstermiştir. Bu olgu, nadir görülmesi ve tanısı torasik ultrasonografi (USG) rehberliğinde transtorasik biyopsi (TTB) ile konulmasından dolayı sunuldu.

Anahtar Sözcükler: Akciğer kanseri; sarkomatoid kanser; ultrasonografi. 